\title{
Role of Career Preference Factors in Predicting Graduates' Employability
}

\author{
W.P.R Wickramaratne \\ 73, Mapanawathura Road \\ Kandy, Sri Lanka
}

\begin{abstract}
The aim of this study was to explore the role of career preference factors in predicting the employability of graduates. A survey was conducted based on a sample of 154 recently passed out graduates who are employed in management faculties as academics of five state owned leading Universities in Sri Lanka. Correlation and regression analyses were performed with the help of SPSS software (version 22) to analyze the collected data.The results found that stability \& expertise and variety \& creativity are positively related to the employability of graduates. Conversely, Managerial and independence \& autonomy do not have significant relationships with employability of graduates. In agreement with the extant literature the graduates are concerned about their job security and seek opportunities to demonstrate skills and knowledge gained from their studies in choosing a career. In contrast to these prior studies, the graduates do not have inspirations to employ in managerial positions that they can enjoy more authority whereas their willingness to have freedom on the job and the autonomy in making decisions are not factors that determine their employability. The outcomes of this study support the predictions made by the integrated model of graduate employability of Coetzee (2008). The implications of the study are also discussed.
\end{abstract}

Keywords: graduates, career preference, employability, Sri Lanka

\section{Introduction}

Over the last three decades, the higher education providers have progressively focused on developing the employability of their graduates (Naidoo and Jamieson 2004). Consequently, the employment outcomes have become a principle driver among students (IEEA 2012). This economic orientation of undergraduate study can be attributed to the developing trends in graduate unemployment and underemployment (GCA 2012).

Within these global trends, the graduates entering the world of work for the first time are faced with many challenges, such as dealing with unemployment, coping with the transition from student to employee, adjusting to their new work environment (Marock, 2008; Pool \& Sewell, 2007) as well asmeeting the employers' skills requirements (Weligamage, 2008).In analyzing the unemployment problem, 'Skills Mismatch' hypothesis, first articulated by the ILO Mission to Sri Lanka in 1971 is still highly influential. For example, the employment opportunities expected by a large number of job seekers are not generated within the economy while their qualifications and skills do not fit for the prevailing jobs (Patabendige, 2007). Hettige (2000) claims that, while there are various reasons, the attitudes of graduates influence to enhance their unemployment. That is, attitudes are identified as critical in the realization of career objectives and the career success (Coetzee, 2008). However, only a limited number of studies have empirically explored the role of psychological elements such as graduates' perceptions of their career preference play an influencing role in making their career decisions (Symington, 2012; Brousseau, 1990). The career preference is about 'a person's way of thinking about their future career' (Coetzee, 2008)whereas individuals' career preferences guide their career moves \& career values as well as represent the motivation for a particular career (Brousseau, 1990). Coetzee (2007) identified four career preference factors namely stability and expertise, managerial, creativity and variety, and autonomy and independence.

The stability and expertise career preference refers to the orientation of individual towards occupations or jobs that offer stability, predictability and the opportunity to develop their expertise in a particular field (Brousseau, 1990; Derr, 1986). The managerial career preference refers to individuals who view upward mobility to positions of successively greater responsibility, influence and authority as career success, whereas the individuals with the preference for autonomy/independence value independence and freedom from external interruptions as the ideal work situation (Derr, 1986). 
The creativity/variety career preference describes the need of individuals for a career that allows them to work on a variety of different tasks that require them to use and develop a wide range of skills, abilities and knowledge in innovative and creative ways (Brousseau, 1990). Research findings by Coetzee (2007) indicate that the stability/expertise and creativity/variety career preferences are significantly associated with the needs of individual for further growth and development as a career value.

\section{Hypotheses}

The following hypotheses for this study were established based on the gaps identified in the extant literature.

H1- Graduates preference for stability and expertise has a significant positive impact on their perceived employability.

H2- Graduates preference for managerial careers has a significant positive impact on their perceived employability.

H3- Graduates preference for autonomy and independence has a significant positive impact on their perceived employability.

H4-Graduates preference for creativity and variety has a significant positive impact on their perceived employability.

H0-Graduate career preference factors do not have a significant positive impact on their employability.

\section{Method}

\section{Country context}

Sri Lanka has a free-education policy from primary to the undergraduate level. However, there is a severe competition among students for securing admission to the state owned Universities since a limited number of students are admitted. Despite the competition for University admission, the graduates have to wait for a long period of time for finding employment opportunities since there is a prolonged issue of unemployment in the Sri Lankan economy. This unemployment issue is being increased continuously since the time of obtaining political independence in 1948 (Patabendige, 2006). According to the annual report of Central Bank of Sri Lanka (2015), the unemployment rate increased to 4.6 percent during 2015, compared to 4.3 percent recorded in 2014. Another major issue associated with unemployment in Sri Lanka is the underemployment. For instance, Ariyawansa (2008) claims that, some Sri Lankan graduates are employed in jobs mostly under low salaries which do not fit with their knowledge and skills developed during their undergraduate studies.

\section{Sample}

A survey was conducted based on a sample of 450 recently passed out graduates who are employed as academics in five leading state owned Universities in Sri Lanka. 90 graduates from each University were selected and the surveys were distributed proportionately among the faculties of management with the assistance of senior assistant registrar of each faculty. Within a faculty, the surveys were distributed among academics on random basis and 154 newly passed out graduates responded to the questionnaire which resulted in a response rate of $34 \%$. The scale developed by Coetzee (2008) was used to measure the graduates' perceptions of career preference whereas the employability was measured by the scale developed by Bezuidenhout (2011).

\section{Measures}

Career preference refers to 'a person's way of thinking about their future career' (Coetzee, 2008). The career preferences of people refer to their exceptional visions about the direction their career should take that steer their career choices. Stability and expertise career preference refers to the orientation of individual towards occupations or jobs that offer stability, predictability and the opportunity to develop their expertise in a particular field (Brousseau, 1990; Derr, 1986). Managerial career preference refers to individuals who view upward mobility to positions of successively greater responsibility, influence and authority as career success (Derr, 1986). Autonomy and independence refers to the preference for independence and freedom from external interruptions as the ideal work situation (Derr,1986). Creativity and variety career preference describes the need of individuals for a career that allows them to work on a variety of different tasks that require them to use and develop a wide range of skills, abilities and knowledge in innovative and creative ways (Brousseau, 1990). Employability refers to those proactive career behaviors and abilities that allow people to obtain or generate work through optimal use of both occupations and career- Meta competencies (Coetzee \& Esterhuizen, 2010). 


\section{Control variables}

This study controlled for age, tenure, and gender presuming that these variables have an effect on employability of graduates.

\section{Results}

$73 \%$ of the graduates who responded to the survey were female whereas $27 \%$ of respondents were male graduates. Out of total respondents, $26 \%$ were lecturers who are on temporary basis whereas 53\% were academic demonstrators. $31 \%$ of respondents were below the age of 25 whereas $69 \%$ of respondents were between 26-30 years old.

Correlations and hierarchical multiple regression analysis were used to test the hypothesised relationships. Hierarchical regression analysis allowed control of the effects of demographic variables such as age, gender, and tenure on the hypothesised relationships. The means, standard deviations, correlations, and Cronbach's alpha coefficients are presented in Table 1. The mean age of respondents was 28 years and the average number of years individuals had been with their organisation was one and a half years. Values on the diagonal represent Cronbach's alpha coefficients, which are above the generally agreed upon lower limit of 0.60 . Therefore, each scale measures study variables with consistancy. Only correlations that reached significance at $\mathrm{p}<.05$ or better are discussed here, but the full matrix of correlations is presented in Table 1.

Table 1 Correlation matrix of variables

\begin{tabular}{lllllllllll}
\hline & Mean & SD & 1 & 2 & 3 & 4 & 5 & 6 & 7 & 8 \\
Age (Years) & 28 & 7 & & & & & & & & \\
Tenure (Years) & 1.5 & .42 & $.301^{*}$ & & & & & & & \\
Gender & N/A & N/A & $.216^{*}$ & $.098^{*}$ & & & & & & \\
Stability\& expertise & 4.37 & 3.64 & $.235^{*}$ & $.749^{*}$ & $.146^{*}$ & .747 & & & & \\
Managerial & 3.31 & 0.58 & $.178^{*}$ & $.253^{*}$ & $.148^{*}$ & .115 & $\mathbf{. 8 7 8}$ & & & \\
Variety \& creativity & 4.02 & 0.47 & $.162^{*}$ & $.195^{*}$ & $.199^{*}$ & $.217^{*}$ & .063 &. $\mathbf{9 2 7}$ & & \\
Independence \& autonomy & 4.00 & 0.50 & $.139^{*}$ & $.271^{*}$ & $.215^{*}$ & .050 & .080 & .062 & $\mathbf{. 7 6 9}$ & \\
Graduate employability & 3.99 & 0.72 & $.211^{*}$ & $.743^{*}$ & $.142^{*}$ & $.238^{*}$ & .111 & $.419^{*}$ & .081 & $\mathbf{. 7 7 2}$ \\
\hline
\end{tabular}

Notes: $* \mathrm{p}<.01$, Alpha scores are presented on the diagonal.

Gender is positively correlated with age $(\mathrm{r}=.216, \mathrm{p}<.01)$ and tenure $(\mathrm{r}=.098, \mathrm{p}<.01)$ whereas age and tenure are positively correlated $(.301, \mathrm{p}<.01)$. The correlation coefficients in Table 1 shows that the demographic factors such as age, gender, and the teneure of graduates have a significant positive relationship with all of the career preference factors and their employability which means that graduates career preferences and employability are increased with the increase of their age and tenure as well as female graduates have more preference on the career preference factors than male graduates. The results of the hierarchical regression are illustrated in the following Table (2).

Table: 2 Hierarchical Regressions Examining the Impact of Perceived Career Preference Factors on Graduate Employability Controlling for Demographics

\begin{tabular}{llllll}
\hline & \multicolumn{6}{l}{ Graduate employability } & & \\
\cline { 2 - 6 } & Step 1 & Step 2 & Step 3 & Step 4 & Step 5 \\
\hline Predictors (Beta): & & & & & \\
\hline Age & $.170^{*}$ & .198 & $.235^{*}$ & $.174^{*}$ & $.162^{*}$ \\
\hline Tenure & $.160^{*}$ & $.193^{*}$ & $.091^{*}$ & $.119^{*}$ & $.172^{*}$ \\
\hline Gender & $.139^{*}$ & $.147^{*}$ & $.143^{*}$ & $.147^{*}$ & $.157^{*}$ \\
\hline Stability and expertise & & $.146^{*}$ & $.148^{*}$ & $.175^{*}$ & $.179^{*}$ \\
\hline Managerial career preference & & & .067 & .082 & .058 \\
\hline Creativity and variety & & & & $.381^{*}$ & $.312^{*}$ \\
\hline Autonomy and independence & & & & & .045 \\
\hline F & $5.355^{*}$ & $5.985^{*}$ & $10.273^{*}$ & $.10 .453^{*}$ & $10.501^{*}$ \\
\hline Adj. R-Sq. & $.038^{*}$ & $.064^{*}$ & $.145^{*}$ & $.168^{*}$ & $.171^{*}$ \\
\hline R-Sq. Change & .047 & .030 & .084 & .026 & .253 \\
\hline Note: $*=\mathbf{0}<.05$ & & & & & \\
\hline
\end{tabular}




\section{Hypothesis testing}

As indicated in step five of the hierarchical regression, the career preference factors such as stability and expertise $(\beta=.179, \mathrm{p}<.05)$, and creativity and variety $(\beta=.312, \mathrm{p}<.05)$, positively impact on graduates' employability when the influences of demographic variables and other career preference factors on employability are controlled. Therefore, empirical findings support hypothesis one (H1- Graduates preference for stability and expertise has a significant positive impact on their perceived employability) and hypothesis four (H4-Graduates preference for creativity and variety has a significant positive impact on their perceived employability) of the study and reject the null hypothesis (HO- Graduate career preference factors do not have a significant positive impact on graduates' employability). However, managerial career preference $(\beta=.058, \mathrm{p}>.05)$ and autonomy \& independence $(\beta=.045, \mathrm{p}>.05)$ do not have a significant positive impact on graduate employability. Therefore, the findings do not support hypothesis two (H2- Graduates preference for managerial careers has a significant positive impact on their perceived employability) and hypothesis four (H4-Graduates preference for creativity and variety has a significant positive impact on their perceived employability) of the study and support the null hypothesis. Based on these empirical findings, the following model can be derived.

Figure 1Model derived from the study

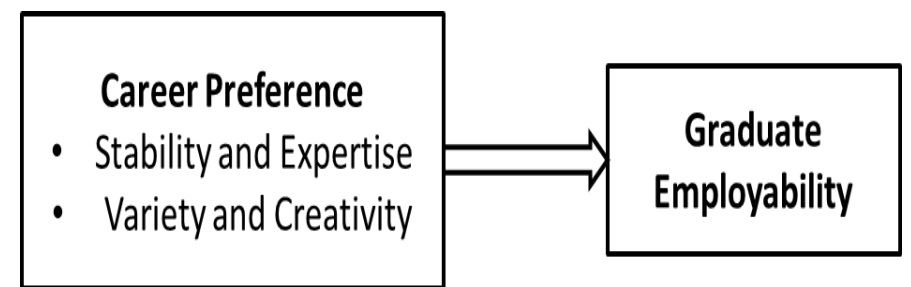

\section{Discussion and Implications}

The finding of the study thatthe graduates' preference for stability and expertise has a positive impact on their employability implies that graduates have a high level of perception to be employed in a job when they believe that there is a job security as well as an opportunity to use their acquired expertise. Similarly, the finding that the variety and creativity has a significant positive impact on the employability suggests that the graduates are more likely to be employable when they perceive that they have an opportunity to apply a range of skills, abilities and knowledge in innovative and creative ways by performing a variety of tasks. There is prior empirical support for the findings of this study (Brousseau, 1990; Coetzee \& Bergh, 2009; Coetzee, 2007; Derr, 1986; Symington, 2012).

\section{Theoretical implications}

The current findings support the predictions of the integrated model of graduate employability (Coetzee, 2008). According to the integrated model of employability, psychological career resources are "career-related orientations, values, attitudes, abilities and attributes that lead to self-empowering career behavior and promote general employability" (Coetzee \& Roythorne-Jacobs, 2007, p.47). As found in this study, graduates' are preferred to have a stable and secured job that they can demonstrate their expertise as well as they are preferred to engage in a job that they can perform variety of tasks and demonstrate their creativity. According to the predictions of the integrative model, the graduates who possess these career preferences are likely to perceive that their employability is high in the job market.

\section{Practical implications}

The study outcomes imply that the graduates' career preference factors play an integral role in determining their employability. Therefore, policy makers of any country should pay attention to career preference factors to uplift the employability of graduates. For example, higher educational institutions should design their study programs in a way that make their graduates capable of carrying out a wide range of tasks relating to a particular job while developing their expertise in that job. Employers also should provide job security and opportunities for graduates to demonstrate their creativity.

\section{Limitations and Suggestions for Future research}

Future studies should investigate other psychological factors such as career values, career drivers, career enablers, and career harmonizers that affect the employability of graduates. 
The selected sample of employees consisted mainly of junior academic staff members of three state owned Universities. Their career preferences may be quite different from other graduates. Therefore, there is a need to investigate graduates who are employed in a wide range of industries. This limitation may affect the generalizability of the findings to the whole country. Results are subject to common method bias and common source since the data for the study were gathered only via a survey. Consequently, a qualitative study is desirable to support the findings.

\section{Conclusion}

This study proposed that graduates may potentially perceive that they have a high level of employability when they are stable in terms of their job security and opportunity to use their acquired expertize. Also, graduates are more likely to perceive that they are employable when they have an opportunity to apply a range of skills, abilities and knowledge in innovative and creative ways by performing a variety of tasks. These results suggest that the psychological factors such as graduate career preference play an essential role to determine graduates employability.

\section{Appendix -A Questionnaire Items}

\section{Preference for stability and expertise}

1. I would prefer a career in which I could develop my skills and knowledge in depth

2. I will feel successful in my career only if I can develop my specialist skills to a very high level of competence and expertise.

3. I would prefer a career that requires me to have special knowledge and skills to perform well

4. I prefer to have a career that will give me a sense of security and stability

5. I prefer a career where I could stay in my chosen field and move up to higher levels of authority and responsibility

\section{Preference for holding managerial positions}

1. I will feel successful in my career only if I become a senior position in an organization

2. I would like to achieve a high level position in an organization

3. I will feel satisfied in my career when I have the authority to make important decisions.

4. I would like to have people reporting directly to me

\section{Preference for variety and creativity in the job}

1. I would prefer a career that offer me much variety and a constant flow of new and unexpected things to do

2. I would prefer a career that allow me to be creative and to work on job tasks that no one else in the group or organization has worked on before

3. I would like a career that allows me to work on a variety of challenging tasks that will require me to use a wide range of skills and knowledge

4. I like opportunities to invent new ideas or things

Preference for independence and autonomy in the job

1.I would prefer a career in which I have the independence to pick and choose my job tasks and projects and to get things done wherever and whenever I choose

2.I prefer the freedom to make my own decisions, set my own schedule and hours, and establish my own priorities

3.I will be most fulfilled in my career when I have been able to build something that is entirely the result of my own ideas and efforts

4.I prefer a career where I would be able to move out of it into new and very different jobs whenever I feel the need to move on to something new 


\section{References}

Ariyawansa R.G. (2008), Employability of Graduates of Sri Lankan Universities. Department of Estate Management and Valuation, University of Sri Jayawardhanapura.

Bezuidenhout, M. (2011). The development and evaluation of a measure of graduate employability in the context of the new world of work. Faculty of economic and management sciences, University of Pretoria.

Brousseau, K.R. (1990). Career dynamics in the baby boom and baby bust era. Journal of Organisational Change Management, 3(3), 46-58.

Central Bank of Sri Lanka. (2015). 2015 annual report. Colombo: Central Bank of Sri Lanka.

Coetzee, M., \& Bergh, Z. C. (2009). Psychological career resources and subjective work experiences of working adults: An exploratory study. Southern African Business Review, 13(2).

Coetzee, M. (2007). Exploratory factor analyses of the Psychological Career Resources Inventory. Unpublished research report, Department of Industrial and Organizational Psychology, University of South Africa, Pretoria.

Coetzee, M. (2008). Psychological career resources of working adults: A South African survey. South African Journal of Industrial Psychology.

Coetzee, M., \&Esterhuizen, K. (2010). Psychological career resources as predictors of African graduates' coping resources: An exploratory study. South African Journal of Industrial Psychology, 36(1), 1-10.

Coetzee, M., \&Roythorne-Jacobs, H. (2007). Career counseling and guidance in the workplace: A manual for career practitioners, Cape Town: Juta.

Coetzee, M., Bergh, Z.C., \&Schreuder, A.M.G. (2010). Subjective work experiences: Exploring the influence of career orientations, psychological career resources and factors of job/career satisfaction/ dissatisfaction. University of South Africa, Pretoria.

Dacre Pool, L., \& Sewell, P. (2007). The key to employability: developing a practical model of graduate employability. Education+ Training, 49(4), 277-289.

Derr, C.B. (1986). Managing the new careerists. San Francisco: Jossey-Bass.

Gibson, J., \& Patabendige, A. J. (2006). Policy reform and labour demand in branches of Sri Lankan manufacturing industry. Applied Economics, 38(12), 1459-1467.

Hettige, S. T. (2000).Students' Counseling and Welfare Service in the University System of Sri Lanka in Talent Development and Utilization. University of Kelaniya, Colombo.

Marock, (2008).Grappling with youth employability in South Africa.

Pool \& Sewell, (2007). Employability attributes and personality preferences of postgraduate business management students. South African Journal of Industrial Psychology.

Naidoo, R., and Jamieson, I., (2004). Knowledge in the marketplace: the global commodification of teaching and learning in higher education, Internationalizing Higher Education, 37-51. Dordrecht: Springer.

Patabendige, A. J. (2007). Skills development through university education: are criticisms made by business leaders against the university education fair? http://repository.kln.ac.lk/handle/123456789/8740.

Symington, N. (2012). Investigating graduate employability and psychological career resources. University of Pretoria, South Africa.

Weligamage S. and Siengthai S.,(2003), Employer Needs and Graduate Skills: The Gap between Employer Expectations, and Job Expectations of Sri Lankan University Graduates, School of Management ,Asian Institute of Technology, Thailand. 